\title{
REPÚBLICA SIN CIUDADANOS
}

Las páginas que siguen tratan de la vertiente opuesta a la utopía andina: el racismo, esa manera peculiar de mirar a los "otros", que además de constituir un discurso sobre la sociedad, integra al entramado de la vida cotidiana.

\begin{abstract}
Alberto Flores Galindo †
\end{abstract}
Este ensayo fue originalmente

presentado como ponencia 1 LA TRADICIÓN AUTORITARIA

un coloquio que sobre En el Perú nadie se definiría como racista. Sin embargo, las historia latinoamericana categorías raciales no sólo tiñen sino que a veces condicionan
organizó Hermes Tovar organizó Hermes Tovar nuestra percepción social. Están presentes en la conformación Alcalá de Henares de grupos profesionales, en los mensajes que transmiten los (Sigüenza, julio de 1987). medios de comunicación o en los llamados concursas de Aproveché de sus belleza, para mencionar algunos ejemplos cotidianos. Pocos comentarios así como han reparado en el contenido racista de una categoría tan también los que me usual en los recuentos censales como es la de "analfabeto", hicieron llegar otros para clasificar así -como un grupo inferior y menospreciado-, a invitados como John Lynch. quienes ignoran el castellano. ${ }^{1}$ El racismo existe no obstante Esta es una nueva versión. que los términos raciales, suprimidos en los procedimientos de La investigación que sustenta identificación pública, no tienen circulación oficial. Pero un este trabajo fue realizada fenómeno por encubierto y hasta negado, no deja de ser me-
bajo el auspicio del Social Science Research Cóuncil (New York). nos real. ${ }^{2}$ Una de las funciones de la historia es enfrentarnos con nosotros mismos, remontándonos hasta cuando

Theodor W. Adorno

\footnotetext{
1 Juan Martínez Allier, Los huacdiilleros de! Perú, París, Ruedo Ibérico, 1973.

2 El psicoanalista Max Hernández ha dicho que Lima actual es una Sudáfnca "solapa": término de jerga que significa encubierta, simulada. En términos parecidos se ha expresado Jorge Eduardo Eielson: "Si ya desde entonces Lima nos parecía tan horrible a algunos de nosotros (...) era porque en ella veíamos el rostió de un organismo enfermo y postrado que se llamaba el Perú. Y esto por más que los viejos y graciosos afeites de una ciudad cortesana, quisieran ocultárnoslo. Para los demás limeñas de entonces, Lima era, en cambio de una ciudad civilizada, limpia y ordenada y hasta, para alguno, aristocrática. Pero aristocracia como es hoy la minoría blanca, anglosajona en Johannesburgh, en Sudáfnca, aún -hay que reconocerlo- sin violencia racista de los aftikaners" (Jorge Eduardo Eielson, "El respeto por la dignidad humana" en El Comercio, Lima, 14 de febrero de 1988, sección D, Pág. 1).
} 
se fueron estructurando concepciones y valoraciones que después queremos ocultar. En este sentido hay semejanza entre el quehacer de un psicoanalista y la función social de un historiador.

Por racismo entendemos algo más que el menosprecio y la marginación: entendemos un discurso ideológico que fundamenta la dominación social teniendo como uno de sus ejes la supuesta existencia de razas y la relación jerárquica entre ellas. El discurso racista en el Perú se estructuró alrededor de la relación blanco- indio y después se propaló a otros grupos sociales. La fuente de este paradigma debemos buscarla en el establecimiento de la dominación colonial. Antes, en el territorio andino existían runas (hombres), que pertenecían a diversos grupos étnicos como los quechuas, aymarás, chocorvos, chachapoyas, chancas. Recién con la conquista surge la categoría de indio, con el propósito de homogenizar forzosamente a la población vencida y reducir sus diversas expresiones culturales a lo que Henri Favre llamaría una "subcultura de la dependencia". Estos propósitos no siempre se cumplieron. Repetidas veces se hizo presente la resistencia andina. Más de un problema terminó derivándose del hecho de que el sistema colonial español se estableciera en el interior mismo del territorio conquistado, requiriendo de incorporar a la población vencida en el circuito productivo. Tras esto está la exigencia creciente de mano de obra para la actividad minera. Domingo de Santo Tomás no fue el único en admitir que eran los indios, y no la plata, la verdadera riqueza del Nuevo Mundo. Pero estas consideraciones no eran compatibles con el divorcio entre la curva de producción minera y la curva demográfica. Para evitar la despoblación y mantener el control de los vencidos, se proyectó el modelo de una sociedad dual, en la que coexistieran dos repúblicas, la de indios por un lado y la de españoles por otro.

La organización del espacio urbano colonial estuvo condicionada por esta segmentación étnica. Así, en Lima, el barrio de los españoles estaba claramente separado del barrio de los indios. Algo similar ocurría con las parroquias. Los libros de bautismo eran también diferentes: en uno se anotaban las partidas correspondientes a españoles, criollos, mestizos, castas y negros y en otro las de indios. Pero esta repartición no era inamovible. A principios del siglo XVIII, para un funcionario español que realizaba una investigación en el Cusco, la población se dividía entre indios y mestizos de un lado, y españoles del otro, los primeros sinónimos de "gente ruin", mientras los últimos eran "vecinos honrados". ${ }^{3}$

Posteriormente, se elaboró una concepción de la sociedad, derivada de Aristóteles, según la cual ésta era equiparable al cuerpo humano: un conjunto de órganos con diversas funciones necesarias entre sí pero claramente jerarquizadas. La cabeza,

3 Bernard Lavalle, "le Marquis el le imrchand", París, CNRS, 1987, Pág. 117. 
por ejemplo, servía para pensar, mientras los pies para caminar, pero la relación vertical era imposible de trastocar a riesgo de generar un monstruo. Naturaleza y sociedad eran inamovibles. Los hombres estaban clasificados de la misma manera que las plantas y los animales. Estas ideas fueron esgrimidas por economistas del siglo XVIII, expuestas desde el púlpito por algunos curas ultramontanos pero también las asumieron escritores reformistas como Baquíjano y otros redactores del Mercurio Peruano, ese supuesto instrumento de la élite ilustrada peruana. Todos creían que la división en estamentos era necesaria para evitar el desorden. Eran hombres que imaginaban al cielo como una apacible jerarquía mientras representaban al infierno como la realización misma del caos.

La sociedad peruana colonial fue bastante menos integrada que sus coetáneas de Europa y por eso, al lado del criterio estamental, coexistieron otros que separaban a los hombres por su nivel de fortuna, por distingos culturales o por las demarcaciones étnicas. Un mismo personaje podía estar emplazado de una u otra manera según el criterio que se adoptase. El criterio más claro en apariencia era el de las castas. Este, sin embargo, era un término ambiguo. De un lado aludía a lo que nosotros llamamos clasificación étnica y de otro servía para denominar a un grupo específico, conformado por el resultado de las diversas variantes del mestizaje negro. Existían por lo menos nueve términos para denominar a cada una de estas "castas": mulato, sambo, tercerón... ${ }^{5}$. Sin embargo, en el Perú las "tablas de raza" no fueron tan frecuentes como en México. ${ }^{6}$

En la sociedad colonial un hombre podía ocupar determinado lugar por su casta y otro, muy distinto, por sus ingresos. ${ }^{7}$ Entender esto último exige considerar que a medida que transcurría el orden colonial se fue desdibujando la identificación inicial entre blanco-colono e indio-colonizado. Fueron apareciendo algunos blancos pobres, establecidos en los pueblos de indios como pequeños comerciantes e incluso como campesinos y que tempranamente los podemos observar, por ejemplo, en ese pueblo de Ollantaytambo reconstruido por Glave y Remy. ${ }^{8}$ En la otra vertiente, la persistencia de una aristocracia indígena creó un sector de indios articulados al aparato de la dominación colonial mediante los curacazgos y los llamados colegios de caciques. Desde fines del siglo XVII podemos observar la formación de familias de indios ricos que conociendo los mecanismos de reciprocidad e intercambio andinos, la legislación colonial y las prácticas mercantiles, ingresan al mundo de los "trajines",

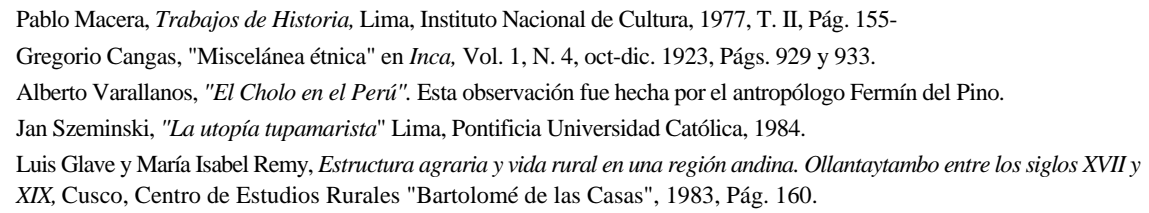


controlan el comercio en localidades del Collao, poseen recuas de mulas, disponen de dinero, ofician como prestamistas y adquieren tierras. ${ }^{9}$ Indio y campesino no eran, entonces, sinónimos. En el siglo XVIII un indio podía ser en términos estamentales un noble como lo eran los Túpac Amaru, los Apoalaya o un hombre rico como de hecho lo fueron los Betancourt, los Choquehuanca, los Huamanpuco. $\mathrm{Al}$ promediar ese siglo, tres familias indígenas controlaban el extenso valle del Mantaro. No era nada desdeñable para un español la alianza matrimonial con cualquiera de estos personajes. Con esto no se quiere sugerir que era fácil la movilidad social en la colonia. Pero es indudable que la rigidez y la pretendida inmovilidad del discurso sobre la sociedad se veía quebrada con frecuencia. Y también debemos considerar que la obsesión clasificatoria no siempre funcionó.

Estos problemas se complicaron durante el siglo XVIII dada la existencia de esa franja intermedia entre la república de indios y la de los españoles que era la población mestiza. En el siglo XVI los mestizos eran evidentemente una minoría pero en 1786 constituían 23 por ciento de la población colonial, distribuidos de manera desigual, predominando en el norte y centro, en Trujillo y Tarma, más que en el sur; en las ciudades antes que en los medios rurales. Junto a ellos habría que considerar a la migración procedente del África. Los esclavos eran una minoría pero estaban concentrados en los valles de la costa central peruana y sobre todo en Lima (25 por ciento de la población) y sus alrededores. Esta heterogeneidad demográfica hará que el discurso de la élite colonial contenga una idea según la cual existía un "cuerpo de nación", para cuyo funcionamiento era necesario el equilibrio entre sus partes. Miguel Marticorena ha encontrado esta concepción repetidas veces, en memorias de virreyes, proclamas y versos de la época. No debe ser confundida con las ideas de nación y nacionalismo que después introducirán los románticos. En el primer caso, el sustento era corporativo. Cuando se tornen frecuentes los motines y sublevaciones rurales, algunos funcionarios coloniales pensarán que la estabilidad del sistema radicaba en compensar el elevado número de indios, colocando al otro lado de la balanza a españoles, mestizos y negros. Lo expresará con transparencia el virrey Gil de Taboada en 1791. Al igual que otros funcionarios, no podía concebir al Perú sin indios, pero confiaba en que "...para cada indio u originario suyo, se hallan 5 y $1 / 8$ de las demás castas". ${ }^{10}$

La población indígena, como consecuencia del colapso demográfico del siglo XVI, estaba concentrada en la sierra pero aunque dentro del espacio colonial existían regiones de desigual desarrollo, no se observan todavía los desequilibrios

9 Luis Miguel Glave, 'Trajines: un capítulo en la formación del mercado interno colonial "en Revista Andina. Cusco, No. $1,1983$.

10 El Virrey Gil de Taboada a Pedro de Lerna, 5 de febrero de 1791, criado por Carlos Deustua, Las Intendencias en el Perú, Sevilla, Consejo Superior de Investigaciones Científicas, 1965. 
posteriores. Lima era la capital de ese vasto espacio. La aristocracia mercantil allí establecida no consigue, a pesar de todos sus esfuerzos, imponerse sobre las élites locales de las ciudades del interior. Se fue gestando así la rivalidad subterránea entre las provincias y la capital. Esto explica que los movimientos sociales de entonces, a su perfil anticolonial, añadan un enfrentamiento contra Lima y su pretenciosa aristocracia. Esos intereses regionales permitirán articular a sectores sociales diversos, desde las capas medias criollas hasta los campesinos indígenas, como los convocados en 1780 por Túpac Amaru. Pero, como ya vimos, la rebelión una vez desencadenada terminaría desbordando sus concepciones iniciales y arrasando con estas propuestas.

"Por cuanto ha llegado a mi noticia que en la provincia de Chumbivilcas se han cometido muchos excesos, matándose los unos a los otros, perjudicándose entre españoles e indios; mando y encargo que de hoy en adelante vivan unánimes, amándose los unos a los otros, viviendo como Dios manda, pena de que no lo haciendo se les castigará y penará en muerte de horca...",

leemos en un bando firmado por Túpac Amaru en Tinta, el 13 de marzo de 1781. Pero en la mayoría de ocasiones sus palabras no fueron acatadas.

Las víctimas de la rebelión tupamarista no fueron esos lejanos personajes de la aristocracia limeña, sino los españoles y los criollos del Cusco (era muy difícil distinguir entre unos y otros), además de esos españoles que vivían entre indios. El volumen de muertos que algunos elevan hasta por encima de los 50.000 y sobre todo la forma como se produjeron estos decesos, las masacres y la intensidad en enfrentamientos que prácticamente dividieron a los pueblos de la zona en dos, dejaron recuerdos casi traumáticos. Se inicia un ciclo literario obsesionado por el indio. La derrota de Túpac Amaru significará, vista desde la otra vertiente, el ocaso de la aristocracia indígena, cuyos títulos fueron suprimidos y, en muchos casos, expropiados sus bienes, acusados con fundamento o no, de haber colaborado con los rebeldes. Atribuyendo el estallido de la rebelión no sólo a factores económicos (los repartos) sino también a factores culturales, la administración colonial arremete contra todo lo que podría ser considerado como cultura andina: prohíben el teatro y la pintura indígena, la lectura de los Comentarios Reales, el uso del quechua, la vestimenta tradicional. ¿Etnocidio? Lo cierto es que el indio comienza a ser tan menospreciado como temido por quienes no lo son. La cultura andina deja los espacios públicos y se torna clandestina. Es entonces cuando los distingos raciales cobran una importancia que no habían tenido antes. Hay que clasificar correctamente la población colonial. Es una de las motivaciones del censo de 1786 y de esos padrones de población que se encargan a los intendentes. Las parroquias se suman a esta tarea. 
El temor a que se vuelva a desencadenar una "guerra de casta" como la de 1780 genera una verdadera tensión étnica. El miedo se propala por mecanismos inesperados. En Lima y la costa se encuentra después con las noticias de la revolución en Haití (junio de 1793) y con el temor de que ese ejemplo sea seguido por los esclavos peruanos. Pero en la sociedad colonial las fronteras étnicas no separan sólo a ricos de pobres. También funcionan en el interior mismo de las "clases bajas", enfrentando, por ejemplo, a indios y negros. Al margen que esas rivalidades fueron espontáneas o fomentadas por la administración colonial, constituyen una de las bases del equilibrio social. El Virrey O'Higgins desecha cualquier temor de una posible rebelión general, argumentando que negros e indios eran irreconciliables. Y, en efecto, las bandas que por entonces asolan los valles de la costa reclutan a criollos, incluso españoles, negros esclavos o no, zambos y mulatos, pero salvo muy rara excepción, indios, quienes en cambio aparecen frecuentemente entre sus víctimas y delatores. En la ciudad de Lima esta rivalidad llega hasta la distribución del espacio urbano: los indios en el barrio del cercado, en las afueras, mientras los negros en el centro o en San Lázaro. En las castas de la ciudad predominan las que son resultado del mestizaje blanco-negro, mientras los "chinos", resultado de la alianza negro-india son una minoría. Terralla y Landa observó ese "total aborrecimiento" que se profesan entre indios y negros. De esta manera podemos decir que los distingos étnicos fueron interiorizados por los propios sectores populares. En esto radicó precisamente su eficacia. Antes que un discurso ideológico, el racismo fue componente de la vida cotidiana colonial.

El ciclo antiindigenista iniciado en 1780 se interrumpe con las guerras de la independencia. Los patriotas admiten que su victoria ha sido posible gracias a tropas indígenas. Surge la idea de integrar al indio en la República como un ciudadano. Es, paradójicamente, uno de los argumentos para suprimir jurídicamente a las comunidades indígenas. Los vencedores, además, se sienten continuadores de los Incas. "He llegado ayer al país clásico del Sol, de los Incas, de la fábula y de la historia", escribirá Bolívar a Olmedo. Vuelven las imágenes de los monarcas incaicos a la iconografía oficial. Aparecen en lienzos pero también en monedas, billetes, sellos oficiales, se los evoca en las estrofas de los himnos o en los versos épicos. Pero lo indio se termina condensando en abstracciones como el sol, los andes, los lagos de altura: imágenes desencarnadas. Más allá de los discursos, se desdibuja el encuentro idílico entre las tropas criollas y los campesinos. Ese sur andino que fue el escenario, prematuro quizá, de las grandes rebeliones de los Amaru y los Catari, se convierte en los primeros años del decenio de 1820, en la segura retaguardia realista. En Ayacucho vencen los patriotas pero en la localidad cercana de Huanta serán hostilizados por curas realistas que cuentan con el apoyo de campesinos, organizados en guerrillas y partidas de montoneros: 
"Como los indios son los que se han portado más mal y más hostilmente en el partido de Huanta, he prevenido al prefecto que les haga pagar el tercio de los tributos que debían entregar en diciembre al gobierno español, eximiendo a los pueblos de Quinua, Acos Vinchos y Huaichao de estos tributos y al pueblo de Quinua de toda contribución porque nos trataron muy bien y sus vecinos dieron al ejército cuanto tenían". ${ }^{11}$

Pueblos enfrentados entre sí. Esa imagen se reiterará en uno y otro lugar. El nuevo país es la imagen más cabal del caos. "Propiamente hablando, el Perú no tiene administración ninguna: es un buque en el cabo sin velas y sin timón", ${ }^{12}$ escribirá Tomás de Heres a Bolívar, quien estará completamente de acuerdo: "nadie obedece a nadie y todos aborrecen a todos". ${ }^{13}$ Una primera explicación se encuentra en el hecho que la independencia trajo consigo el derrumbe de la clase alta colonial. Esa aristocracia limeña primero se vio afectada por las reformas borbónicas y el crecimiento de un polo rival en el Atlántico, el puerto de Buenos Aires. Después perdió el control que ejercía sobre el Reino de Chile y el Alto Perú. La supresión de los repartos afectó al funcionamiento de su red mercantil. Al final vino la guerra, la destrucción de su marina mercante, la emigración a Brasil, a la península o la precipitada huida al Callao y la Sierra tras los pasos de los ejércitos realistas. Hasta el último momento esos comerciantes limeños se mantuvieron en el bando fidelista. No extraña que los bienes de muchos de ellos fueran expropiados por el Tribunal de Secuestros.

La lista de los emigrados sería muy larga. En ella hemos podido ubicar a cerca de cincuenta comerciantes. En los años que siguieron, más de cuarenta haciendas, la mayoría ubicadas en la costa central, pasaron a manos del nuevo estado. Cuando el 20 de septiembre de 1822 se instala el Primer Congreso Constituyente, que debería establecer las bases jurídicas de la nueva república, sobre 91 diputados entre titulares y suplentes, sólo figuran nueve comerciantes y un número similar de propietarios. La mayoría de representantes serán abogados, médicos, eclesiásticos y militares, procedentes de las capas medias provincianas. Este frágil sector social no conseguirá sustituir a la aristocracia colonial. Muy tempranamente se torna evidente el vacío de poder como consecuencia del radical cambio político que trajo la independencia. Antes que se cumpla un año, José de la Riva Agüero, un exconspirador y caudillo en ciernes, se amotina contra el congreso iniciando la tradición de los golpes militares. A su vez, sería depuesto en noviembre de 1823.

Vicente Lecuna. Documentos referentes a la creación de Bolivia.. Caracas, 1924. Cara de Sucre al Ministro de Guerra, Huamanga, 5 de diciembre de 1825. Pág. 26.

12 Bouronde Cornejo. La confederación Perú- Boliviana. Pág. 8.

13 John Fisher, "La formación del Estado peruano (1808-1824) y Simón Bolívar", en Problemas de la formación del Estado y la Nación en Hispanoamérica". Bordan Verlag Köln Wien, 1984, Pág. 467. 
Estos acontecimientos, para más de uno, demostrarían la precariedad de cualquier proyecto democrático en el Perú. Bemardo de Monteagudo en sus Memorias escritas en Quito (1823) va a señalar, junto a otros factores como la distribución de la riqueza, a esas diferencias étnicas siempre tan abismales en el Perú, que llegan a amenazar incluso la misma "existencia social". No estaba pensando sólo en la separación entre blancos e indios. Pensaba más bien en la existencia de castas diversas contrapuestas entre sí. La fragmentación social del mundo colonial se ha agudizado con las guerras de la independencia. En Lima y otros lugares, Monteagudo observa "hombres que forman tantas subdivisiones sociales, cuantas modificaciones hay en su color", todo lo cual es a su entender incompatible con "las ideas democráticas". ${ }^{14}$ La revolución no modificará de manera significativa el entramado cotidiano. Para las más radicales la independencia implicaba aparte de romper con España, la liquidación de la aristocracia colonial. Esto último lo conseguirían tanto por las circunstancias (la crisis de esos años) como porque se lo propusieron (la política antiespañola). En cambio el ámbito de las relaciones domésticas pasó inadvertido. Por allí terminará prolongándose el orden colonial. La República heredará los conflictos y las marginaciones raciales.

\section{EL DISCURSO RACISTA}

El derrumbe del orden colonial fue seguido por los años anárquicos de la iniciación de la República. No fue posible que los caudillos militares consiguieran una estabilidad política como la que estableció Diego Portales en Chile. Al Estatuto Provisorio de 1821, siguieron unas bases elaboradas en 1822 y después las constituciones de 1823, 1826, 1828, 1834 y 1839. El mariscal Agustín Gamarra, uno de los gobernantes que consiguió mayor estabilidad durante esos años, debió enfrentar catorce intentos subversivos. Heraclio Bonilla se ha referido a la situación de un país a la deriva. Hubo que esperar hasta los años 40 ó 50 del siglo pasado para que se iniciara la recomposición de clase alta peruana. Las rentas de las aduanas primero y las exportaciones guaneras después, permitieron la conformación de rápidas fortunas familiares.

En el proceso de recomposición de la clase alta un episodio de particular importancia fue la consolidación. El pago de la deuda interna contraída durante las guerras de la independencia se comenzó a hacer efectivo a partir de 1850. Se trataba de convertir en dinero constante esos "papelitos" que los generales patriotas habían entregado, durante las guerras de la independencia, a todos aquellos que sufrieron alguna requisa: dueños de haciendas, comerciantes, arrieros, pequeños propietarios... Una variedad de personajes que incluía a quienes habían tenido grandes fortunas y a quienes sólo habían podido aportar con su caballo, su acémila o la magra cosecha de su parcela. Con el tiempo se había depreciado esos vales y

14 Bernardo Monteagudo, Memoria sobre los principios políticos que seguí en la administración del Perú, Santiago de Chile, Imprenta Nacional, 1823, Págs. 18-19. 
habían pasado de mano en mano. Algunos especuladores las fueron adquiriendo y luego ejercieron toda la presión de que disponían para conseguir que el Estado procediera a pagarlos. Durante la administración de Echenique alcanzaron ese objetivo. Quienes se vieron beneficiadas terminaron por ser una minoría no mayor de cincuenta personas, vinculados al comercio de exportación y unidos con lazos de clientelaje al régimen. Todo esto ocasionó un terrible escándalo. Se habló de falsificación de documentos. La palabra consolidado fue incorporada al diccionario como sinónimo de estafa y peculado a costa del erario público. Este hecho sería uno de los factores que desencadenó la sublevación de Castilla. Triunfante la rebelión de 1855, si bien se abolió la esclavitud y se suprimió el tributo indígena, al poco tiempo se repitieron los mismos procedimientos de la administración anterior en el pago de la deuda, agravados por manejos similares para indemnizar a los propietarios de la casta por la manumisión de esclavos. Se produjo el nuevo alzamiento, esta vez dirigido por Vivanco, pero sin éxito. ${ }^{15}$

Los consolidados terminaron dilapidando sus fortunas. Habría que esperar algunos años para que con base en el guano y el comercio de exportación se recomponga de manera consistente la clase alta peruana. Entonces se estableció un rudimentario circuito financiero que permitió el flujo de capitales del comercio a la agricultura de exportación, a través del pago a los bonos de la deuda interna, la manumisión de esclavos o los préstamos del Banco Central Hipotecario. Estos últimos estuvieron abrumadoramente dirigidos a los departamentos de la costa norte y central. Los valles allí ubicados vieron cambiar rápidamente a sus paisajes con la expansión de la caña de azúcar y el algodón. Se establecen ingenios y desmotadoras, llegan los tractores a vapor, se realizan obras hidráulicas. Estos beneficios no alcanzarán al sur del país motivando los reclamos de la clase alta arequipeña. El eje económico del país se traslada de la sierra a la costa. El espacio nacional se desequilibra en beneficio de Lima y los puertos: son los costos del crecimiento basado en la agricultura de exportación. La costa peruana termina más cerca del Asia que del "hinterland" andino: de allá proviene la mano de obra que sustentará a esa supuesta burguesía guanera. Esos ingentes capitales no permitieron la conformación de un mercado de trabajo. Demasiado tarde se piensa que esta desarticulación puede ser un problema y se concibe entonces el proyecto de una red ferroviaria que articule a los puertos con la sierra.

Apareció en Lima una burguesía particular, provista de capitales pero sin fábricas y sin obreros. Podría resumirse en la relación de treinta apellidos como Aspíllaga, Ayulo, Barreda, Larco, Pardo... Entre los pocos que supervivieron de la antigua aristocracia colonial podrían mencionarse a los Ramírez de Arellano (que pudieron conservar algunas de sus haciendas) o esos Mariáteguí, que luego de años difíciles, salieron a flote gracias al productivo enlace de una hija con Enrique Swayne y

15 Alfonso Quiroz, La deuda defraudada, Lima, Instituto Nacional de Cultura, 1987. 
Wallace, socio de una firma de Liverpool. Este no fue el único extranjero que hizo fortuna. De manera tal que esa clase alta que emergía no sólo era numéricamente reducida, sino además joven (una o dos generaciones en el país) y en cierta manera extranjera o demasiado europea para un país cuya población mayoritaria era indígena. Aunque la consolidación, como vimos líneas atrás, fue un fenómeno relativamente pasajero y breve, allí estuvo el origen de una profunda fisura entre el Estado y el país. Los escándalos de entonces y la concentración del dinero público en pocas manos, hicieron que la naciente "opinión pública" de entonces perdiera toda confianza en la administración estatal. Se trataba de pequeños propietarios, artesanos, comerciantes, intelectuales que habían tenido su primera experiencia política durante las elecciones de 1850 . No obtuvieron nada esperanzador de los votos pero tampoco del levantamiento liderado por Castilla. Habían llegado ecos de la revolución de 1848 y algunos jóvenes imaginaron que algo similar podría ocurrir en el Perú. Evidentemente no fue así. Aparecieron la frustración y el desengaño. Nada de esto era terreno propicio para el consenso. Aquí está una de las fuentes de esa imagen de Jorge Basadre según la cual la República ahondó el abismo entre el país legal y el país real.

¿De qué manera un grupo tan reducido pudo controlar un país tan vasto, desarticulado y conflictivo como el Perú de entonces? Durante la colonia el orden social contaba con el respaldo de la idea monárquica y la garantía que eran ejércitos peninsulares contra cualquiera que pretendiera cuestionar al Rey. La república se erigió justamente sobre la debacle del ejército realista. Otro sustento importante de la aristocracia colonial era la Iglesia. Pero la independencia había implicado también una ruptura con el clero. La jerarquía bendijo hasta el último momento a las tropas del Virrey. El Papa León XII confeccionó una encíclica para instar a permanecer en la obediencia a Fernando VII. Después el Vaticano se negó a reconocer a la nueva república y sólo en 1852 sería admitida la primera legación peruana en Roma. El Perú del siglo XIX, por uno u otro motivo, voluntario o no, era una sociedad cada vez más profana que en su ordenamiento político reclamaba, por lo tanto, criterios terrenales.

En tiempos del Rey, tres instituciones habían permitido el funcionamiento de la dominación social en las zonas del interior: el corregidor, autoridad española a escala provincial, encargado de administrar justicia; el curaca, la autoridad correspondiente en la República de indios y que se desempeñaba como bisagra entre las comunidades y la administración colonial; el cura, que además de velar por las almas, era un propalador de normas y valores desde el pulpito y el confesionario. Al terminar el siglo XVIII los corregidores fueron reemplazados por los intendentes y éstos, después de la independencia, por los prefectos pero la república no pudo otorgarles un respaldo siquiera equivalente al que el estado colonial daba a sus funcionarios. Paralelamente, los nexos con la Iglesia se debi- 
litaron. El clero tendió a disminuir a lo largo del siglo XIX y en su composición comenzaron a predominar los extranjeros: 3.000 sacerdotes en 1820 a 2.400 en 1874. Algunas órdenes desaparecen: prematuramente (1767) los jesuitas, después los betlemitas. Ambas corporaciones habían poseído algunas de las haciendas más extensas y eficaces del agro colonial. La Iglesia irá perdiendo sus propiedades. En la provincia de Azángaro (Puno) de 40 haciendas de la Iglesia y capellanías que existen en 1829, un siglo después sólo quedan 11. Al promediar el siglo pasado se suprimió el diezmo. Se resquebrajan las bases materiales del clero. La Iglesia pierde poder en el campo. Comienzan a verse los primeros templos abandonados. Aunque para algunos indigenistas como el narrador Narciso Arestegui, el cura es uno de los flagelos del indio, es evidente que han perdido el poder. En lo que respecta a los curacas, como ya señalamos, fueron suprimidos después de la derrota de Túpac Amaru y los remanentes de esta institución, anulados por un decreto de Simón Bolívar expedido en 1824, en el Cusco. Todas estas circunstancias llevaron a Bartolomé Herrera a decir que "el principio de la obediencia pereció en la lucha de la emancipación" (1842).

La desaparición de curacas y corregidores, la postergación del clero y la debilidad de los aparatos policiales y burocráticos republicanos, permitieron que los terratenientes, a la propiedad de sus haciendas añadieran el monopolio del poder político local. Con la república adquirieron un poder que no habían tenido antes. En el siglo XIX un hacendado podrá movilizar a sus "propios indios", con los que formará partidas de montoneros y huestes particulares. Así se conforman los ejércitos que participan en las guerras civiles al lado de Vivanco, Castilla o Echenique. La clase alta costeña para poder constituirse en la clase dominante del país, debió admitir un acuerdo implícito con los terratenientes del interior. Tolerando sus prerrogativas y sus fueros privados se aseguraba que éstos controlasen a los campesinos. En las haciendas funcionaba una reciprocidad asimétrica. El propietario permitía que sus "colonos" usufructuaran tierras y ganado, a cambio de trabajo y/o productos; les conseguía coca y aguardiente, les daba protección librándolos por ejemplo del servicio militar. Para denominar a esos propietarios se acuñó un peruanismo que después tendrá curso corriente en las ciencias sociales: gamonal. Fue necesaria para denominar una situación inédita derivada de la fragmentación política y la ruralización del país. El poder de los gamonales sería una síntesis entre el uso de mecanismos consensúales, con la violencia ejercida cara a cara. El gamonal no fue un propietario absentista. Conocía muy bien a sus campesinos con los que podía comunicarse en quechua pero con la misma frecuencia utilizaba el látigo y el cepo. El personaje era una mezcla de racismo con paternalismo. ${ }^{16}$

Para estos lemas me remito a las primeras páginas de mi ensayo "El horizonte utópico". 
La modernización iniciada durante la era del guano -a partir de 1840 cuando comienzan las expoliaciones de este abono-, fue acompañada con la casi inevitable reproducción de la servidumbre. El poder terminó compartido entre la burguesía de Lima y la costa y los hacendados tradicionales del interior. A esta forma de querer organizar el país se le ha denominado "estado oligárquico". El término oligarquía sirve para designar el ejercicio minoritario y excluyente de la dominación. La imprenta admitió esta palabra en 1877, como título de un folleto elaborado por José Andrés Torres Paz, La Oligarquía y la crisis, donde se denunciaba a una clase social constituida con "dinero ganado sobre todo en los negocios del guano, cuyo auge contrastaba con el abatimiento y la degradación del pueblo y que pretendía elevarse políticamente sobre las ruinas del detestable caudillaje militar". Pero esta afirmación para conservar su validez debe circunscribirse a Lima y parte de la costa. Mientras la capital crece y se derrumban sus murallas coloniales, otras ciudades como Cusco, inician una irreversible decadencia. En 1865, el viajero Squier dirá que "en Lima se sabe mucho menos del Cusco que de Berlín; por cada nativo de la capital que ha visitado el Cusco, hay cien que han visitado París. El viaje de Lima a Nueva York se hace en menos tiempo que el que se puede hacer desde el mismo punto hasta la altiva pero aislada ciudad de la sierra y con una cuarta parte de sus molestias". ${ }^{17}$

En 1876, un censo plagado de fallas en las cédulas, en las encuestas y hasta en el mismo recuento final, atribuía al Perú una población de casi 2’700.000 habitantes. De ellos 371,195 eran blancos, contrastando con la mayoritaria población indígena compuesta por 1'554.678 pobladores, establecidos en su mayoría en la sierra y en los medios rurales. Más de medio millón fueron clasificados como mestizos. Las minorías negra y asiática tenían una proporción similar: algo más de 50.000 personas cada una. Para los blancos -incluso sólo por estas consideraciones numéricas-, los indios constituían un problema. Santiago Távara algunos años antes, se había preguntado: "y estos indios a quienes llamamos ciudadanos, ¿de qué servirán a la república?". ${ }^{18}$ Su respuesta no podía ser muy optimista por el solo hecho de describir al indio como un sujeto receloso, vil y bajo, abatido, temeroso y desconfiado. El lado pasivo e inerte de la sociedad.

Una visión similar podemos encontrar en quien elaboró los textos escolares de historia utilizados entonces. Un español llamado Sebastián Lorente (1813-1884), hombre de ideas liberales, profesor en el colegio Guadalupe en Lima y fundador del colegio Santa Isabel en Huancayo (1851), autor de una Historia de la Civilización Peruana y de varios manuales sobre el período prehispánico, la conquista, la colonia y la independencia,

17 George Squier, Un viaje por tierras incaicas. Crónicas de una expedición arqueológica (1863-1865), Buenas Aires, 1974, Pág. 247.

18 Santiago Távara, Emancipación del indio decretada el 5 de julio de 1854, Lima, Jasé María Mónterola, 1856, Pág. 20. 
escritos hacia 1866. Lorente fue quien contribuyó de manera más directa a modelar la conciencia histórica de los niños y jóvenes peruanos que asistían a la escuela o de cualquier adulto que supiera leer. Sustentó su versión de la historia peruana en un esquema general que admitía la existencia de razas. Por entonces, habían llegado al Perú las ideas de Gobineau y fueron admitidas muy rápidamente. Lorente encontró en ellas la clave para cualquier explicación histórica. Distinguir entre razas opresoras y razas oprimidas le permitió compadecer al indio, que desde siempre se había encontrado en esta última situación, y reprochar a la vez la "prosperidad" y "locura" de los dominadores. Sin embargo, por estar oprimido, el indio era la misma negación de valores modernos como el cambio y el progreso: un personaje carente de cualquier energía. ${ }^{19}$ Estos rasgos eran tanto psicológicos como físicos.

"Con la opresión secular llega a deteriorarse el cuerpo junto con las dotes del espíritu: la fisonomía de ciertos indígenas ofrece el aire de las razas decrépitas, hay ausencia total de lozanía, falta de frescura, que anima las razas llenas de juventud y de porvenir". ${ }^{20}$

Era el resultado de la milenaria opresión del "comunismo teocrático" de los Incas, capaz de convertir a cualquier pueblo en una máquina, y de la acción posterior del colonialismo, de manera tal que ese ánimo aletargado y torpe que Lorente atribuye a los indios, sólo podría extirparse en el transcurso de "varias generaciones". En el futuro inmediato no podía contarse con ellos. En sus Pensamientos sobre el Perú, obra publicada en 1855, presenta a los indios al margen de cualquier civilización y su prosa termina desbordada por adjetivos despectivos:

"Yacen en la ignorancia, son cobardes, indolentes, incapaces de reconocer los beneficios, sin entrañas, holgazanes, rateros, sin respeto por la verdad, y sin ningún sentimiento elevado, vegetan en la miseria y en las preocupaciones, viven en la embriaguez y duermen en la lascivia". ${ }^{21}$

Es decir, los indios convertidos en el depósito de todos los valores negativos. La imagen invertida del blanco. No es fácil encontrar en la historia anterior del país a un escritor que siendo tan influyente en su sociedad, propusiera un discurso tan abiertamente racista y agresivo contra los indios, todo ello a pesar de estar considerado como uno de los hombres de avanzada y figurar incluso entre los radicales de entonces. Para Lorente el indio termina degradado hasta la escala animal. Un cierto pudor lo lleva a atribuir el juicio a otros: "Alguno ha dicho: los indios son llamas que ha-

Gonzalo Portocarrero, "La historia del Perú en la divulgación escolar" (Inédito).

Sebastián Lorente, Historia de la civilización peruana. Lima, Imprenta Liberal, 1879- Ver también Historia del Perú, compendiada para el uso de los colegios y de las personas ilustradas, Lima, Aubert y Loisseau Editores, 1866.

21 Sebastián Lorente, Pensamientos sobre el Perú, Lima, Universidad Nacional Mayor de San Marcos, 1967, Pág. 23. 
blan". ${ }^{22}$ Pero hace la cita sin ninguna aclaración ni desmentido. Todavía más: no se trata de cualquier animal sino de una "estúpida llama". Una imagen similar circuló entre los intelectuales enemigos de Santa Cruz en los tiempos de la Confederación. Pero es al promediar el siglo pasado que, junto con la recomposición de la clase alta peruana, termina por cristalizar este discurso racista sobre la sociedad.

Es asumido por el Mariscal Ramón Castilla: el caudillo más importante del siglo pasado, a quien se le atribuye la organización de la administración pública republicana y a quien el ejército peruano ha querido esculpir con los rasgos de héroe y conductor. Para Castilla la solución del problema nacional requería fomentar la inmigración de "hombres robustos, laboriosos, morales, y cuya noble raza cruzándose con la nuestra mejore". ${ }^{23}$ Una visión enteramente biológica de la sociedad. Esos posibles inmigrantes eran la negación del retrato del indio hecho por Lorente: debían ser blancos, occidentales, europeos. Como esos pocos tiroleses que se establecieron en el Pozuzo o los vascos que fueron a Talambo. Pero se trata de excepciones. La inmigración que llegó al Perú durante esos años estaría compuesta en su mayoría por asiáticos, hombres que para Castilla eran todavía más endebles y ociosos que los mismos indios; venían para trabajar en las haciendas pero terminaban huyendo para refugiarse en pueblos y ciudades: "allí mezclados con nuestros naturales pervierten su carácter, degradan nuestra raza e inoculan en el pueblo y especialmente en la juventud, los vicios vergonzosos y repugnantes de que casi todos están dominados". ${ }^{24}$

Durante las dos administraciones de Castilla, año a año se fue incrementando el número de chinos que llegaban al Callao, hacinados en barcos procedentes de Macao. Estos hombres desarraigados que llegaban a un país cuya lengua ignoraban, sin habérselo propuesto, contribuyeron a que paradójicamente cuando los esclavos eran libertados, la clase alta peruana y su élite intelectual y política asumieran con entusiasmo el racismo: les permitía justificar su dominación, los convencía que su dominio por más violento que fuese, tenía una razón de ser.

En 1847 se inició la reconquista de la amazonía, Ramón Castilla autorizó a una expedición militar que penetró a "sangre y fuego" en la selva central y estableció un fuerte en San Ramón. ${ }^{25}$ Desde allí fueron frecuentes las expediciones punitivas. Comenzaron a llegar los colonos. Los nativos, como en el siglo XVIII, volvieron a sublevarse. En una ocasión emboscaron a una comisión oficial de marinos. En represalia se organiza una expedición comandada por Benito Arana (1866). La región del Cerro

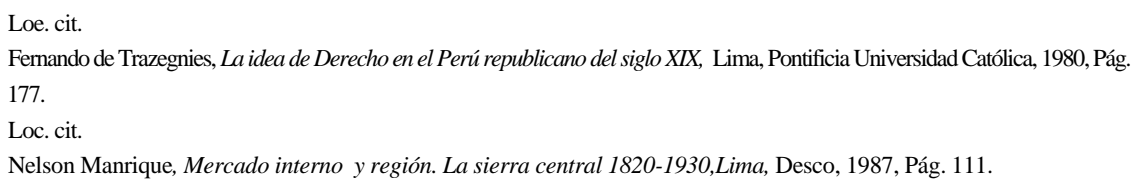


de la Sal volvía a ser una frontera militar, en la que de un lado estaban los civilizados y del otro "los salvajes". Aunque no fuera motivo de noticias o informaciones periodísticas, en esos parajes se desató lo que Pablo Macera ha llamado "una guerra de exterminio terrible". El racismo tuvo un correlato demasiado dramático para algunos sectores de la población peruana.

La violencia continuó siendo un elemento vertebral en la dominación social. Tanto la que podía ser ejercida abiertamente sobre migrantes chinos o habitantes de la amazonía, como la que se realizaba cotidianamente en las haciendas. Durante los años en los que cristaliza el discurso racista, un porcentaje significativamente alto del gasto público estará destinado a finalidades militares: el 48\% en 1849, 37\% en 1852 y 51\% en $1862 .{ }^{26}$ El ejército llegó a tener alrededor de 10.000 hombres sobre las armas. Pero en su estructuración interna traslucía las fracturas de la sociedad peruana: más del 80\% de sus efectivos estaban acantonados en Lima y El Callao, y oficiales y tropa contrastaban por su composición social. Los soldados eran indios o mestizos, llevados de manera compulsiva y carentes de lo que un observador inglés llamaba "esprit de corps": "La mayoría de los oficiales, especialmente los de los rangos superiores, son descendientes de los antiguos colonizadores españoles, y por ello tienen bastante poco en común con sus hombres". ${ }^{27}$

Un ejército con estas características sólo podía acabar derrotado ante una invasión extranjera. Cuando se desencadena el conflicto con Chile (1879-1883), en medio de la crisis política y del consiguiente desorden, se desencadenan los conflictos que se venían acumulando. Los chinos se incorporan al ejército invasor cuando sus tropas llegan al valle de Cañete pero no para pelear bajo su bandera, sino que aprovechan la ocasión para entregarse al espontáneo saqueo y ataque contra las haciendas. En Lima -sin mayores evidencias-, se sindicará a los asiáticos como los culpables del incendio de Chorrillos, cuando esta localidad es ocupada por las tropas chilenas (enero de 1881). Casi enseguida, en el puerto de El Callao serán saqueadas las tiendas de los chinos y no pocos, asesinados.

La derrota servirá para que algunos intelectuales, como Manuel González Prada, cuestionen a una República establecida a costa de la población indígena, sin haberle reconocido a éstos una efectiva ciudadanía. Pero en muchos otros escritores el efecto fue inverso: achacaron el fracaso y la frustración a la inferioridad del indio, al lastre que constituía para el desarrollo nacional. Chile venció porque tenía menos indios y más europeos que el Perú. Su ejército, incluso, se había adiestrado antes de la guerra en el exterminio de los Mapuches. En 1881 -en

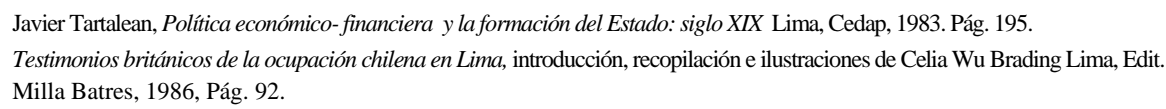


plena ocupación- un profesor de la Universidad de Arequipa señalará como la causa de la derrota al estéril mestizaje entre españoles e indios. Años después, en 1894, Javier Prado y Ugarteche insistirá en la "influencia perniciosa que las razas inferiores han ejercitado en el Perú". Francisco García Calderón envidiará a países que, como Chile o Argentina, están libres de "razas agotadas"28. Llegamos así hasta Clemente Palma, quien resumirá el pensamiento de muchos intelectuales peruanos al afirmar en un libro escrito en 1897, que "la raza india es una rama degenerada y vieja del tronco étnico del que surgieron todas las razas inferiores. Tiene todos los caracteres de la decrepitud y la inepcia para la vida civilizada. Sin carácter, dotada de una vida mental casi nula, apática, sin aspiraciones, es inadaptable a la educación". ${ }^{29}$ En los años 20 de este siglo, el filósofo y catedrático universitario Alejandro Deústua, dirá sin ambages ni atenuantes, que el "Perú debe su desgracia a la raza indígena". ${ }^{30}$

En 1885, cuando el viajero alemán Ernst Mieddendorf visitó Huaraz (poco antes esta población había sido amenazada por una rebelión campesina), llegará a sentir en el ambiente toda la tensión generada por el áspero conflicto racial entre indios y blancos. "Los conflictos entre razas distintas no pueden solucionarse sobre la base de principios de justicia y las guerras raciales son siempre guerras de exterminio". ${ }^{31} \mathrm{Si}$ tomamos en serio a Pardo, Palma y Deustua, sus ideas conducían a plantear en estos términos antagónicos y definitivos, el llamado problema indígena.

\section{SE NECESITA EMPLEADA}

En sus Pensamientos sobre el Perú, Lorente incluye un texto titulado "El cholito". Allí nos hace una curiosa confidencia: "Cuando salís para la sierra, las señoritas de Lima no dejan de pediros un cholito y una cholita, y a veces os encargan tantos, que juzgaríais se encuentran en los campos por parvadas". ${ }^{32}$ ¿Qué era un cholito? diminutivo de cholo, sinónimo de "indio muchacho", por lo general, huérfano o forastero, destinado al servicio doméstico. En el periódico El Comercio en ocasiones se podían encontrar avisos requiriendo a un muchacho o una muchacha para trabajar en dicho oficio: "Se necesita con urgencia para el servicio de un matrimonio sin hijos, un cocinero o cocinera y una sirvienta de mano". ${ }^{33}$

Jeffrey Klaiber, "Los "cholos" y los "rotos": actitudes raciales durante la guerra del Pacífico" en Histórica, vol. II, N. 1, julio 1978, Pág. 311.

Clemente Palma,, El porvenir de las razas en el Perú, Lima, Torres Aguirre, 1897,Pág. 15.

Alejandro Deústua, La cultura nacional. Lima, 1937.

Ernst Middendorf. Perú. Observaciones y estudios del país y sus habitantes durante la permanencia de 25 años,. Lima. Universidad Nacional Mayor de San Marcos, 1973, t. III, Pág. 53.

32 Sebastián Lorente, Pensamientos sobre el Perú, Lima, Universidad Nacional Mayor de San Marcos, 1967, Pág. 29.

33 El Comercio, Lima, año XX, No. 5894,3 de enero de 1859. 
El Comercio fue fundado en 1839. Los primeros números tenían sólo dos páginas, pero desde el inicio ese periódico fue publicando una sección compuesta por avisos breves al precio de cuatro reales la primera vez y dos reales las siguientes veces en que se reproducía el mismo texto. En los primeros años se pueden leer ofertas de artesanos, solicitudes de profesores, avisos sobre esclavos fugados, algún profesor que se ofrece para enseñar idiomas... Esta sección constituye una puerta de ingreso a la vida cotidiana limeña. A medida que transcurren los años se vuelven frecuentes los avisos en los que se busca empleados domésticos para una función específica como cocheros, lavandera o ama de leche como, por ejemplo: "Se necesita un cocinero de buena conducta para que sirva en una casa de familia; la persona que quiera alquilarse con ese objeto ocurra (sic) a esta imprenta donde se le dará razón". ${ }^{34}$ Después el lector encontrará avisos sobre "cholitos" o "cholitas" que se han fugado, perdido, han sido raptados o convencidos de trasladarse a trabajar a otra casa. Estos avisos se repiten al promediar el decenio de 1840 y todavía más, en el siguiente. Salen dos o más en cada número. Es raro, en cambio, encontrar un aviso solicitando un cholito. Los avisos se refieren a sirvientes que están trabajando ya en Lima. Esto llevaría a pensar que son reclutados fuera de la ciudad, a través de algún viajero ocasional como Lorente cuando iba a la sierra, de algún familiar (prefecto o hacendado). El servicio doméstico parece ser una prolongación del pongaje (del servicio personal) que los campesinos realizaban en la casa hacienda.

La descripción de los sirvientes buscados por sus patrones es muy sintomática de la manera de ver a los otros que tenían tanto la clase alta como las capas medias de entonces. Se trata casi siempre de menores de edad, predominan los muchachos, apenas se indica el nombre y en cambio se abunda en los rasgos físicos -hasta a veces indicar características dentales-, y casi siempre se describe la vestimenta. Personajes sin nombre propio descritos como si se tratara de objetos. Veamos algunos ejemplos de fines de los años 50.

"De la casa situada junto a la caballeriza de Mr. Gárate No. 649, se ha salido hoy un serranito nombrado José, natural de Huarás, lleva la cabeza y los pies desnudos, blusa de género de pequeñas rayas azules desteñidas. La persona que lo entregue recibirá una gratificación". ${ }^{35}$

"Aviso - Anoche ha fugado de la casa de sus patrones un muchacho de siete a ocho años de edad, llamado Gregorio, casta indio, gordo, cara redonda, ñato; varias cicatrices en la frente; muy cerrado para hablar el castellano, como hijo de una de las provincias de Ayacucho; ha salido vestido con una camisa de color morado, pantalón de casimir plomo, sin sombrero ni zapatos". ${ }^{36}$

$34 \quad$ El Comercio, Lima, no. 181,12 de diciembre de 1839.

35 El Comercio, Lima, año XX, no. 5750,7 de agosto de 1858. 
"Aviso interesante - La persona que hubiese encontrado un chico a las doce y media del día de ayer 29 de julio, se suplica que se vaya a la calle Riva No. 109 que se le dará una buena gratificación, sus señales son: labios gruesos, cabezón, gordito, un poco trigueño y tiene cuatro años de edad". ${ }^{37}$

"Aviso- Ayer lunes 9 se ha fugado de la tienda de la Inquisición No. 155 una muchacha de servidumbre nombrada Flora de edad de diez años; se previene a la persona en cuyo poder esté, la entregue inmediatamente si no quiere exponerse a las consecuencias que le resulten por ocultarla contra el reglamento de Policía, pues la patrona de ella que la ha criado hace veces de madre" .58

Los sirvientes eran incorporados, aunque en un plano inferior y claramente diferenciado, a la vida doméstica y en ocasiones hasta a la propia familia. Este aparente paternalismo permitía disponer de trabajo gratuito o justificaba el recurso a castigos físicos. Algunos eran enrolados desde muy niños. La frecuencia de los avisos indica que, no obstante todo lo anterior, muchos se resistían y fugaban. En 1836, Lima tenía más de 55.000 habitantes; treinta años después duplicó su población. Este crecimiento demográfico acelerado, que debió desconcertar a los limeños de entonces, hacía de la ciudad un lugar adecuado no necesariamente para perderse, sino para huir y encontrar un trabajo alternativo (en alguna otra casa) o tal vez ocultarse. Pero esos frecuentes avisos se refieren a casos donde parece sospecharse que el sirviente ha sido convencido por uno u otro medio para trabajar con otro patrón. Si recordamos los reclamos que recibía Lorente, es plausible pensar que, por entonces, se había incrementado la demanda de sirvientes. ¿Explicaciones? El crecimiento urbano ya señalado pero también los cambios en el nivel de vida. Un signo exterior de riqueza era la cantidad de servidores como antes, durante la colonia, había sido el número de esclavos.

Este hecho -el número de sirvientes- no podía pasar inadvertido para los viajeros europeos. Middendorf, por ejemplo, describe entre los rasgos típicos de Lima, la cantidad de criados que se podían encontrar al servicio de una familia: "La servidumbre de una casa se compone por lo menos de tres personas: un cocinero, un mayordomo y una muchacha o auxiliar de la señora. Los sirvientes son, por lo general, cholos, o zambos, con excepción del cocinero, que frecuentemente es chino, y excepcionalmente francés. En las casas más ricas se añade todavía un portero, un segundo mayordomo que ayuda en la mesa al primero, un pinche de cocina o lavador de platos, una lavandera, costurera y tantas criadas como el número de niños lo exija". ${ }^{39}$ Esta descripción se refiere a Lima

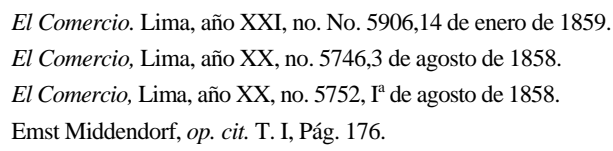


después de la ocupación chilena. En los años anteriores, hacia 1855, en plena era del guano, no hay razón para suponer que el número de sirvientes fuera menor.

En el servicio doméstico se puede observar una cierta estratificación. De un lado, aquellos que tienen un oficio específico o que requiere alguna preparación especial y, del otro, los que se ocupan de todo y hacen una labor casi exclusivamente manual. Los primeros vienen desde muy atrás y se los encuentra entre las familias más acomodadas, en cambio, los segundos pareciera que se encuentran también entre familias de capas medias o incluso de menores recursos. Ellos han sustituido a los antiguos esclavos. En 1854 se abolió la esclavitud. Desde los inicios de la república el número de esclavos había decrecido significativamente en la ciudad. Una vez libres, pocos siguieron como sirvientes. En cuanto a los chinos que entonces llegaban a El Callao, en su mayoría fueron a trabajar en las haciendas. Raro fue el incorporado a alguna casa. ¿Por qué? Tal vez con ellos no se podía mantener las vinculaciones paternalistas que en cambio sí se entablaban con los "cholitos", a quienes amos o patronas conocían desde niños, así como también podían conocer a sus padres. Pero el rasgo más importante es el hecho de tratarse de menores de edad, porque en otras ocasiones llegaban a Lima traídos compulsivamente, sin poder regresar donde sus familias, en situación de desarraigo que los condenaba a una dependencia total. En los avisos citados antes vemos el caso el niño Gregorio a quien se lo califica como "cerrado" para el castellano. Como él muchos otros conocerían quechua o aymara y apenas unas pocas palabras en español. No había interés por educarlos y el desconocimiento de la lengua de los amos o el hablarla con un marcado acento, era otro elemento de diferenciación.

El racismo no sólo tenía que ver con una interpretación de la historia peruana o con proyectos políticos; también formaba parte del entramado mismo de la vida cotidiana, estaba presente en el ámbito doméstico y se aprendía desde temprano, cuando los niños que nacían en esas casas de Lima observaban cómo sus padres trataban a esos cholitos, que podían tener la misma edad y eventualmente compartir algún juego con el hijo del jefe de familia.

El "cholito" era un forastero, en una ciudad cada día más grande, sujeto a lazos de dependencia rígidos, obligado a servir en todo momento, a estar dispuesto a cumplir con los requerimientos, demandas y exigencias de sus patrones. El poder total a escala doméstica. De una sumisión semejante sólo se podía salir recurriendo a la fuga. No faltó el caso extremo: eliminar al dueño. Algunos crímenes que conmovieron a la ciudad tuvieron como protagonistas a un sirviente con varios años de trabajo como asesino, y a sus amos como víctimas.

De acuerdo con el censo de 1876, el servicio doméstico era la actividad más importante de Lima: 6.460 habitantes figuran como domésticos. Si a ellos añadi- 
mos los que se desempeñaban como lavanderas, cocheros, nodrizas, caballerizos, mandaderos, el número total llegaba a cerca de 9.000: el 10\% de la población de la ciudad y entre el $20 \%$ y el $30 \%$ de la "población ocupada". ${ }^{40}$ El número de mujeres era ligeramente mayor que el de varones. Para esa fecha no tenemos datos sobre la procedencia étnica de los sirvientes. En cambio, en el censo de Lima de 1908, cuando los sirvientes en Lima ascienden a 14.274, alrededor del $19 \%$ de la población ocupada, sabemos que la mayoría eran indígenas y después venían los mestizos, pocos eran "amarillos" (es decir, asiáticos) y todavía menos los negros. ${ }^{41}$ Oficio de "cholos". Al comenzar estas páginas decíamos que el racismo en el Perú había tomado como paradigma las relaciones entre señores e indios existentes en las haciendas andinas. Estas relaciones se reproducían en el ámbito doméstico. Llegaban a la ciudad. Lima fue el centro de irradiación de la ideología racista.

Pero la servidumbre urbana no era un fenómeno nuevo. Podemos rastrear sus antecedentes en los conventos de Lima que recurrían siempre a una elevada cantidad de servidores, en aquellos niños entregados como aprendices en los talleres de artesanos, pero encontramos sirvientes también en casas particulares junto a esclavos y desde fechas muy tempranas, como el año 1613. En el padrón de indios de esa fecha, de un total de 1978 indios censados, 451 eran sirvientes. De ellos 274 era varones y 177 mujeres. La inmensa mayoría (alrededor de 90\%) eran solteros. Predominaban los menores de edad y el desarraigo observado para los años 50 del siglo pasado, se podía también observar a comienzos del siglo XVII: $47 \%$ de los sirvientes no tenían ni encomendero, ni cacique. ${ }^{42}$ Tiempo después, más de un siglo, para el año 1771 tenemos un padrón de Lima correspondiente al barrio de Cocharcas donde encontramos que fueron censados 244 sirvientes, repartidos desde casas que tenían uno (47\%) hasta las que contaban con 19 sirvientes -una sola-. ${ }^{43}$

Entonces la servidumbre doméstica era una antigua institución urbana, tan vieja como la ciudad. Cuando se piensa en la herencia colonial, convendría reparar en que logró reproducirse a través de mecanismos como éste. Pero si bien hay una cierta estructura invariable que puede llegar hasta nuestros días, en los años cincuenta del siglo pasado, cuando se formulaba de manera tan explícita el discurso racista, el servicio doméstico no sólo se incrementó como consecuencia de la manumisión de esclavos, sino además apareció una especie de mercado de "cholitos".

\footnotetext{
40 Real Ministerio de Gobierno, Censo General de la República del Perú formado en 1876, Lima, Imprenta del Teatro, 1878, T. VI(Lima).

41 Perú, Dirección de Salubridad Pública, Censo de la provincia de Lima (26 de Junio de 1908), decretado y levantado durante la administración del Excmo señor don José Pardo..., Lima, Imprenta de la Opinión Nacional, 1915.

42 Noble David Cook, Pachón de Indios de Lima de 1613, Lima, Seminario de Historia Rural Andina, 1968.

43 Mauro Escobar, "Un padrón de Lima -1771".
} 
Esos "cholitos" fueron la realización extrema de un rasgo de la sociedad peruana: la simbiosis entre los criterios de clase social y de casta. Queda demostrado de manera tan evidente cuando reparamos en que sirviente doméstico y cholo eran sinónimos. Pero cholo era además un término despectivo: en algún momento equivalente a perro, siempre a persona de baja condición. El cholo era el vástago de una raza vencida e inferior, a la que sólo quedaba la sujeción. En apariencia o en todo caso así creían sus amos. 